\title{
Molar Root-length as an Indicator of Age in Clethrionomys gapperi
}

\author{
M. R. PERRIN ${ }^{1}$
}

Perrin M. R., 1978: Molar root-length as an indicator of age in Clethrionomys gapperi. Acta theriol., 23, 28: 423-434 [With 2 Tables \& 4 Figs.].

A population of redbacked voles, Clethrionomys gapperi, from the boreal forest of southeastern Manitoba was studied in order to monitor changes in molar root-length occurring with age. Molar roots develop at approximately three months of age and there was subsequently a direct linear relationship between the length of the anterior of the first lower molar and age. The growth rate did not vary seasonally. No significant differences between sexes occurred in the growth rates of molar roots in either the laboratory or the field. However, significant differences in growth rate did occur between laboratory-reared and wild-caught voles. Young voles without molar roots were aged by body weight.

[Environmental Res. Branch, Whiteshell Nuclear Res. Establishment, Atomic Energy of Canada Ltd., Pinawa, Manitoba, Canada, ROE 1LO.]

\section{INTRODUCTION}

Accurate age determination is important in understanding the ecology of a species, because it makes possible the estimation of parameters such as growth rate, age at sexual maturity, and longevity. Growth rate of molar tooth roots has often been used as an indicator of age in Clethrionomys populations, and the method is here applied to C. gapperi. The absolute growth rate of the anterior root of the first lower molar was used in this study, although a ratio method ( $\mathrm{Z}$ i mmerman, 1937) and/or the second molar have also been used ( $\mathrm{K}$ os h k in a, 1955).

Alternative techniques for ageing Clethrionomys species have also been considered. The degree of ossification of tail vertebrae $(\mathrm{H}$ a g e $\mathrm{n}$, 1955) appears to be unsatisfactory. The eye lens technique has been more valuable (A skan er \& H ans s o n, 1967), but in C. gapperi, eye lens weights vary seasonally (P e r r in, unpubl.), rendering that technique of questionable applicability.

1 Present address: Dept. Zool. Entomol., Rhodes University, P.O. Box 94, Grabamstown, 6140, South Africa. 
This study was designed to investigate the growth rate of molar roots of known-age laboratory-reared voles released into the field, and to apply these rates to voles captured from wild populations. Since it was expected that molar roots in C. gapperi would not develop until two or three months of age, changes in body weight were examined in laboratory voles with a view to developing an ageing technique for juveniles and sub-adults.

\section{METHODS}

Six hundred C. gapperi were snap-trapped between November 1973 and December 1974 in a black spruce (Picea mariana) forest $2.8 \mathrm{~km}$ northeast of the Whiteshell Nuclear Research Establishment at Pinawa, Manitoba. Sphagnum covered approximately half of the forest floor. The commonest shrubs were Ledum groenlandicum and Rubus idaeus, with Rubus pubescens, Epibolium angustifolium and Cornus canadensis as the commonest herbs (I vers on \& Turner, 1973). Museum Special snap-traps baited with peanut butter were set biweekly for four consecutive nights. The lower jaw was removed from each of the voles taken, and the first molar removed at a later date.

Known-age voles were reared in a laboratory colony. Excess food and water were continually available, and the animals were maintained at $23^{\circ} \mathrm{C}$ with a $15 \mathrm{~L}: 9 \mathrm{D}$ photoperiod. Laboratory voles were weaned at four weeks and treated to a vital alizarine staining technique ( $\mathrm{L}$ o w e, 1971). This technique marks the calcium being deposited in the molar roots at the time of treatment and provides a temporal and physical reference point for measuring growth rates.

Over 200 six-week-old laboratory-reared voles were released on several different occasions throughout the summer of 1973. Release was into an area where large numbers of C. gapperi had been removed by continuous trapping for two weeks. Attempts to recapture the released animals commenced after about one month's interval. Other known-age laboratory voles were killed at regular intervals to determine molar root growth rate and changes in body weight in the laboratory.

Lower molars were removed from the jaws of field and laboratory animals by the following procedure. The jaws were placed in individual boiling tubes in a $1 \%$ solution of papain and wbiological " detergent, and maintained at $90^{\circ} \mathrm{C}$ for eight hours. The first lower molar $\left(M_{1}\right)$ was then extracted with forceps after the other molars had been similarly removed.

After extraction, each tooth was examined dry under a low-power $(40 \times)$ stereomicroscope with a micrometer eyepiece and a dark field, to measure the distance between the crutch beneath the crown, and the distal end of the larger anterior root (Fig. 1). All measurements were made on the buccal surface of the first lower molar, from a line perpendicular to the crutch, to the centre of the anterior root tip. The mean root length for each biweekly sample was determined for the field population, and root length of animals taken from the laboratory colony was plotted against age.

Regression analysis was used to examine the relationships between molar root length, and time or age respectively, in wild-caught and laboratory reared voles. Sex differences in the laboratory and field voles were also examined. 


\section{RESULTS}

Trapping success of the released known-age laboratory-reared voles, that had been treated with alizarine, was extremely low (approximately $2 \%$ ) which forced the abandonment of this part of the experiment. Growth of molar roots was therefore examined in the laboratory colony.

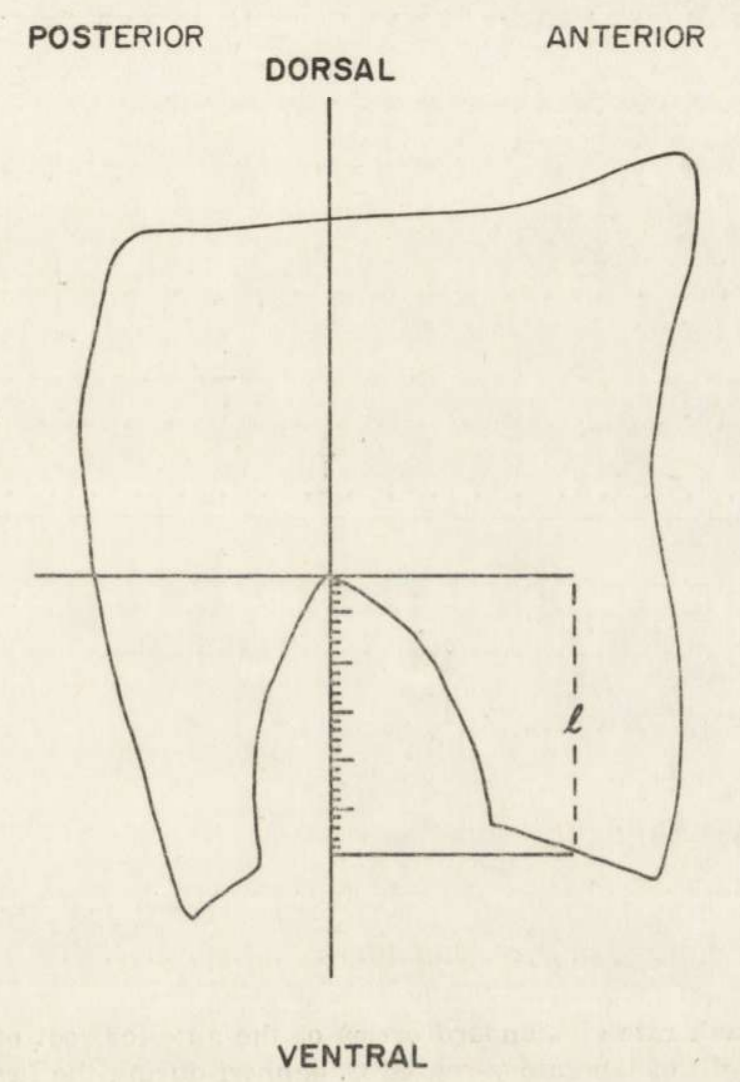

Fig. 1. Buccal aspect of the first right mandibular molar $\left(M_{1}\right)$ showing the position of the eye-piece graticule relative to the crutch beneath the crown for measuring the length $(l)$ of the anterior root.

\subsection{Molar Root Growth Rate in Laboratory-reared Voles}

The growth rate of molar roots of laboratory-reared voles (from lateborn cohorts) was essentially linear and can be expressed by the linear regression equation: $y=84+204 x$ where $y=$ age in days, and $x=$ molar root length $(\mathrm{mm})\left(r=0.95, r^{2}=0.90, N=50, p \leq 0.01\right)$. 
A correlation analysis performed between age and molar root length of laboratory-reared voles from different cohorts (Fig. 2) between 60 and 290 days old also suggested a positive and highly significant correlation ( $\left.r=0.82, r^{2}=0.67, \mathrm{~N}=44, p \leq 0.01\right)$. However, the correlation was not as good as that for a single cohort.

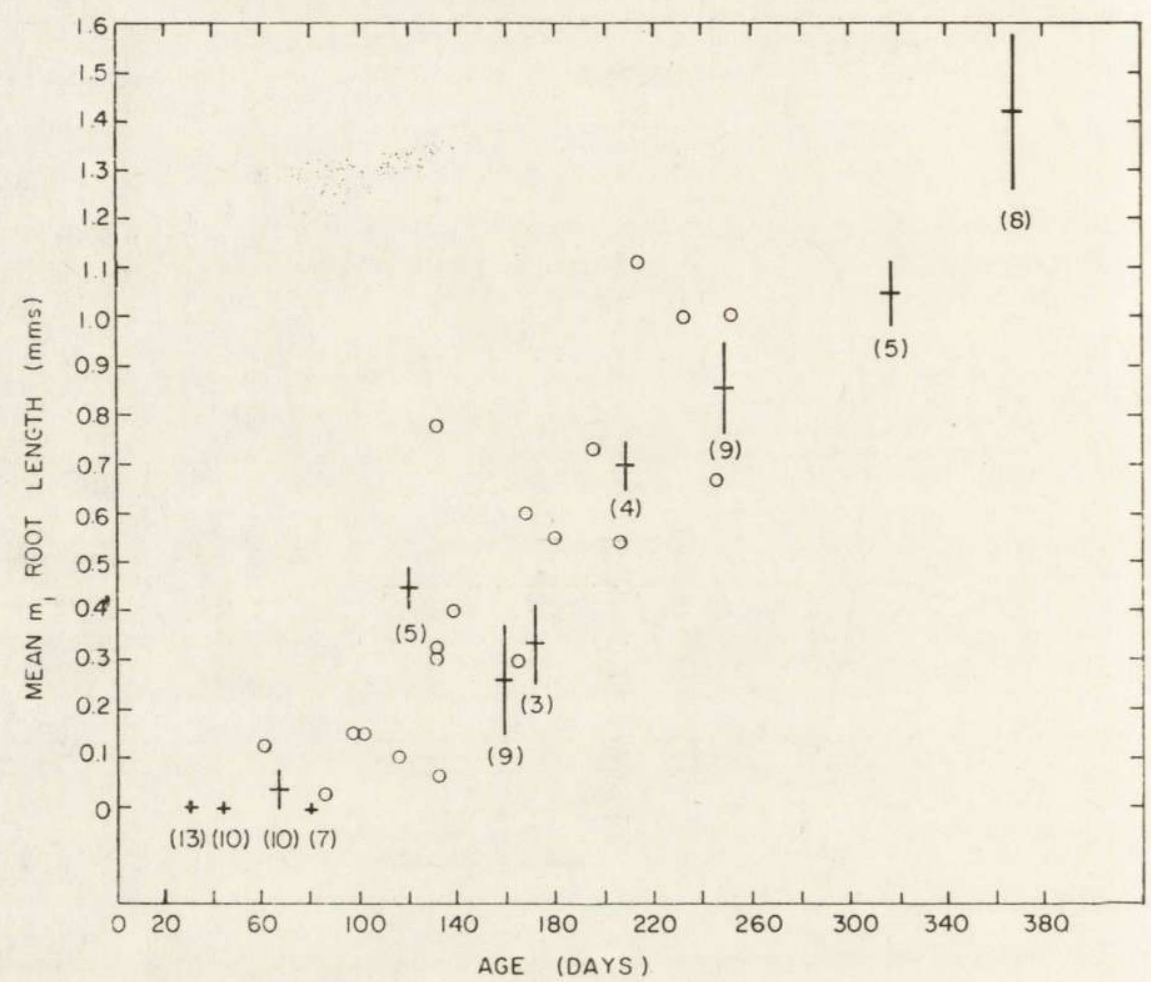

Fig. 2. Mean growth rate ( \pm standard error) of the anterior root of the first mandibular molar $\left(M_{1}\right)$ of laboratory-reared $C$. gapperi during the first year of life

$\mathrm{O}$ indicates individual voles. Numbers in parentheses are sample sizes.

There were no significant differences between the sexes in relation to age and molar root length. For males, $y=86+207 x,\left(r=0.96, \mathrm{r}^{2}=0.92\right.$, $\mathrm{N}=25, p \leq 0.01)$ and for females $y=79+206 x\left(r=0.95, r^{2}=0.90, \mathrm{~N}=25\right.$, $p \leq 0.01$ ). In all cases it was apparent that molar roots developed at approximately 80 days of age in laboratory-reared voles.

\subsection{Molar Root Growth in Wild Voles}

There was a direct linear relationship between the length of the anterior root of $M_{1}$ and time in wild C. gapperi (Fig. 3). Time was measured 
in days from the centre of the breeding season, i.e., 1st July. Hence the regression equations indicated the rate of growth of molar roots, but not the age at which roots developed.

The equations for males and females were very similar, i.e. $y=116+$

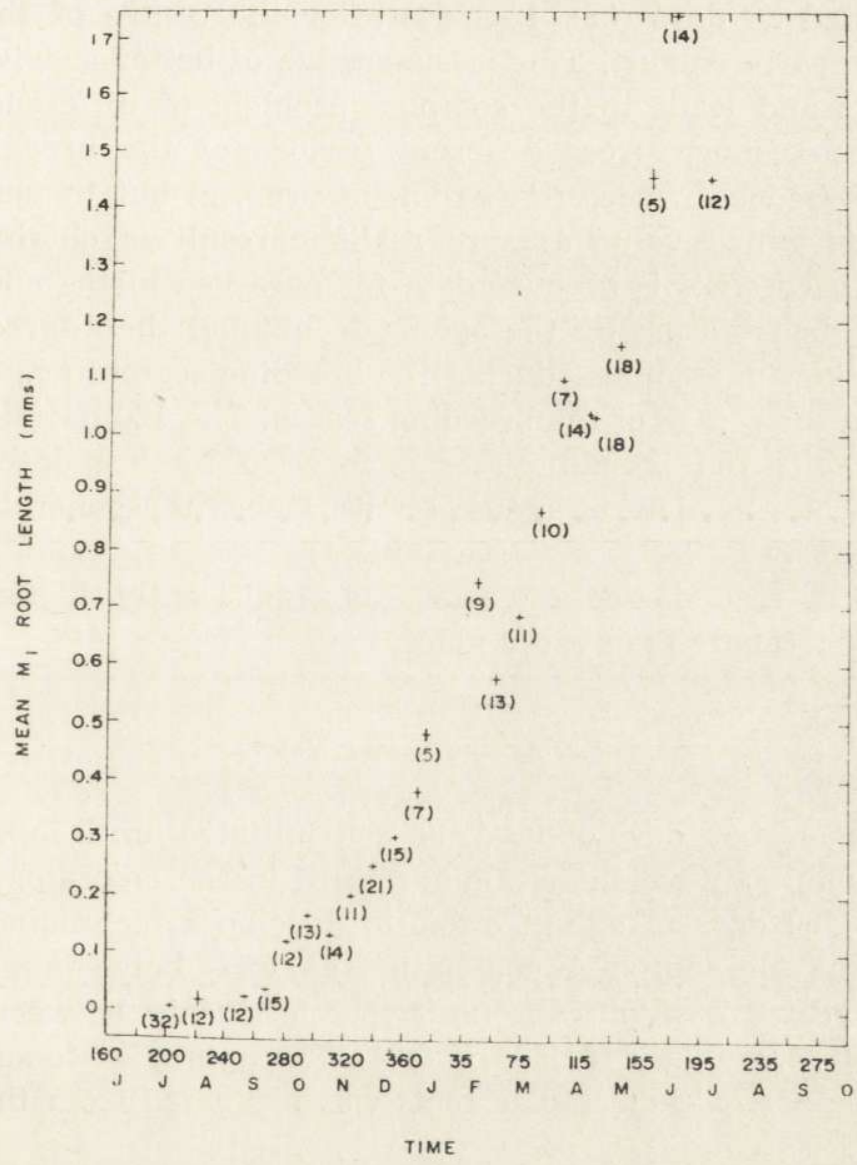

Fig. 3. Mean growth rate ( \pm standard error) of the anterior root of the first mandibular molar $\left(M_{1}\right)$ of wild $C$. gapperi over a single annual cycle.

Time in days is indicated from the first of January. Sample sizes are shown in parentheses.

$+156 x\left(r^{2}=0.84, \mathrm{~N}=188, p \leq 0.01\right)$, and $y=124+163 x\left(r=0.87, r^{2}=0.76\right.$, $\mathrm{N}=158, p \leq 0.01$ ) respectively. Therefore an expression was developed for both sexes combined, i.e., $y=120+158 x,\left(r=0.89, r^{2}=0.79, \mathrm{~N}=346\right.$, $\mathrm{p} \leq 0.01)$. 
The intercept figure represents the time taken for molar roots to develop, plus the mean length of time after the centre of the breeding season when the animals were recruited (in days). If the figure of 84 days (from the laboratory study) is used to account for the development of molar roots in the field, then it appears that on average most voles were recruited 36 days (i.e., $120-84$ ) after the centre of the breeding season, or in early August. This in suggestive of better survival by lateborn cohorts and leads to the complex problem of differences in survival between cohorts from different periods of the breeding season. This is discussed elsewhere ( $\mathrm{Per}$ rin, in prep. a) but by using the laboratory-determined value a more realistic result is obtained than if 120 days is used. This is because data for observed births and predicted births (from back-dating by the ageing technique) then agree well, and there is no skewing of births during the breeding season; i.e., most births occur during the centre of the breeding season. The 120 day figure would effectively shift the breeding season forward by a month, which is incorrect because of data on actual births. Hence the general expression is represented by $y=84+158 x$ (see Table 1 ).

The growth rate of molar roots was significantly higher in wildcaught than in laboratory-reared voles.

\subsection{Ageing Young Voles}

Since molar root development is not initiated until approximately 80 days of age, body weight was determined in the laboratory for young voles up to 100 days of age in order to develop a technique for ageing juveniles and sub-adults. A correlation analysis between body weight and age indicated a significant positive relationship between the parameters, $\left(r=0.93, r^{2}=0.86, \mathrm{~N}=50, p \leq 0.01\right)$. The approximate age of known weight $C$. gapperi without molar roots was estimated from the following expression,

$$
\log y=0.0866 x+0.1762
$$

where $y=$ age in days, and $x=$ body weight in grams (see Table 2).

\subsection{Application to Wild Caught Voles}

The two equations derived in this study, that is for voles under approximately 100 days of age (based on body weight), and for those older (based on molar root length), were applied to the wild population snaptrapped during 1973 and 1974 (Fig. 4). Recruitment from different cohorts of young, or a shift in the timing of the breeding season, may have 
accounted for younger voles in November and December of 1973, as compared with 1974 . The overwintered population, and the young of the year, represented two distinct age-classes during summer and early

Table 1

Age of wild C. gapperi in relation to molar root length.

\begin{tabular}{cccc}
\hline $\begin{array}{c}M_{1} \begin{array}{l}\text { length, } \\
(\mathrm{mm})\end{array} \\
\text { Age in days }\end{array}$ & $\begin{array}{c}\text { Male, } \\
\text { Age in days }\end{array}$ & $\begin{array}{c}\text { Female, } \\
\text { Age in days }\end{array}$ \\
\hline .05 & 92 & 92 & 92 \\
0.1 & 100 & 100 & 100 \\
0.2 & 116 & 116 & 117 \\
0.3 & 130 & 131 & 133 \\
0.4 & 147 & 146 & 149 \\
0.5 & 163 & 162 & 165 \\
0.6 & 179 & 178 & 182 \\
0.7 & 195 & 193 & 198 \\
0.8 & 210 & 209 & 214 \\
0.9 & 226 & 224 & 231 \\
1.0 & 242 & 240 & 247 \\
1.2 & 274 & 271 & 280 \\
1.4 & 305 & 302 & 312 \\
1.6 & 337 & 334 & 345 \\
1.8 & 368 & 365 & 377 \\
2.0 & 400 & 396 & 410 \\
\hline
\end{tabular}

Ages for the mean (both sexes), male and female classes are predicted from $y=84+158 x, y=84+156 x$, and $y=84+163 x$ respectively (where $y=$ age in days, and $x=$ molar root length in $\mathrm{mm}$ ).

Table 2

Age of young $C$. gapperi in relation to body weight.

\begin{tabular}{cc}
\hline Body weight, $\mathrm{g}$ & Predicted age, days \\
\hline 12.0 & 16.4 \\
13.0 & 20.0 \\
14.0 & 24.5 \\
15.0 & 29.9 \\
16.0 & 36.5 \\
17.0 & 44.5 \\
18.0 & 54.3 \\
19.0 & 66.3 \\
20.0 & 80.9 \\
\hline & \\
Ages are predicted from log $X=0.0866$ \\
$Y+0.1762$, (where $X$ age in days, and \\
$Y=$ body weight in grams).
\end{tabular}

autumn when they coexisted. The overwintering age-class became progressively less variable in its age range, presumably owing to differential mortality. A more detailed interpretation is presented elsewhere ( $\mathrm{P}$ e r$\mathrm{r}$ i $\mathrm{n}$, in preparation (a)). 


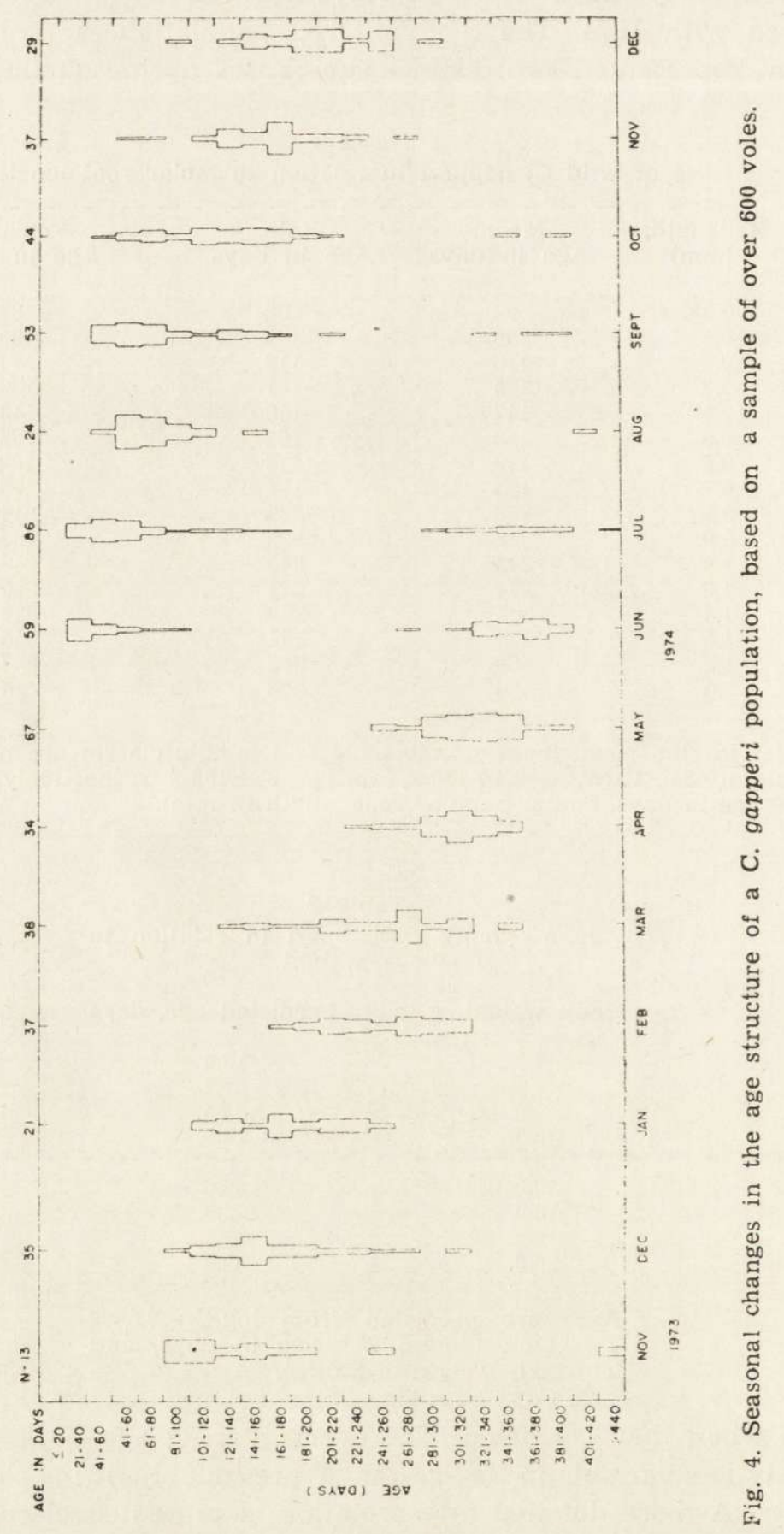




\section{DISCUSSION}

Numerous authors have used the growth rate of molar roots to age several species of Clethrionomys. Chances in molar root-length occurring with age were first recorded by Röhring \& Borner (1905), and the first ageing technique was developed by $\mathrm{Z}$ i m m e r m a $\mathrm{n}$ (1937) who compared the ratio of root-length to total tooth height. Several recent studies have utilized the ratio method (K o sh kin a, 1955; $\mathrm{T}$ upikova, Sidorova \& Konovalova, 1968; Viitala, 1971) but have used the second molar $\left(M_{2}\right)$ rather than the first $\left(M_{1}\right)$. The first molar is larger, but the second is more easily exposed and is symmetrical ( $\mathrm{T} \mathrm{u} \mathrm{p} \mathrm{i} \mathrm{k} \mathrm{o} \mathrm{v} \mathrm{a} \mathrm{et} \mathrm{al.,} \mathrm{1968)} \mathrm{and} \mathrm{hence} \mathrm{more} \mathrm{easily} \mathrm{measured.} \mathrm{Most} \mathrm{workers,}$ however, have based ageing techniques on the absolute length of the first molar (Wrange l, 1939; Prychodko, 1951; Pucek \& Zej$\mathrm{d}$ a, 1968). Age can only be determined by this method, of course, after root development has commenced, which normally occurs at approximately 2-3 months of age (Wrange 1, 1939; Prychodko, 1951; W a silewski, 1952; Z e j d a 1955; Z e j da, 1961; M a zák, 1963; Haitling er, 1965; Tupikova et al., 1968).

Similar mean growth rates of molar roots, of between 0.15 and $0.18 \mathrm{~mm}$ per month, have been demonstrated in several independent studies (P r ychodk o, 1951; W a sil e w ski, 1952; Z e j d a, 1961; M á z a k, 1963). In this study molar roots develop at approximately 84 days of age, and the mean rate of growth was approximately $0.19 \mathrm{~mm}$ per month (between 100 and 400 days of age).

There were only slight sex differences in molar root growth rates and a single formula may be applied to all adult $C$. gapperi. In C. rufocanus the growth rate of molar roots in females increases significantly above that of males in summer (Vi itala, 1971). This rapid growth rate in females ( $0.39 \mathrm{~mm}$ per month) and consequent wear of molar crowns and growth of their roots might be associated with an increase in feeding and energy requirements owing to pregnancy and lactation ( $\mathrm{K} \mathrm{a} \mathrm{c} \mathrm{z} \mathrm{m} \mathrm{a} \mathrm{r-}$ ski, 1966). Lowe (1971) has suggested that differences between the sexes are complex, and vary according to their different physical and sexual maturation rates, but no further information is given.

In C. glareolus, tooth growth rates vary between cohorts, i.e., in relation to the time of birth ( $\mathrm{L}$ ov e, 1971). However, the breeding season of C. gapperi in southeastern Manitoba is much shorter than that of C. glareolus in England, and the difference between cohorts is thought to be less exaggerated. Nevertheless, future studies should aim to separate cohorts, and measure molar root growth rate separately for each sex and cohort. 
The growth rates of molar roots of C. gapperi in this study were higher in natural than in laboratory conditions. In other studies this has been related to the laboratory diet ( $\mathrm{L}$ o w e, 1971; V i it a l a 1971), which probably produces insufficient abrasion of the occlusal surfaces. The C. gapperi laboratory colony in this study was fed hay, oats and hard laboratory pallets, and although molar growth rates were significantly lower than in wild voles, differences were not as great as those recorded in other studies (L o w e, 1971).

The growth rate of molar roots provides a basis for ageing adult C. gapperi with some reliability, and is sufficiently accurate for ecological and population studies (P e r r i n, in prep. a). Wherever possible, corrections should be made for season, sex and cohort, and a known-age series should act as controls.

Young voles cannot be aged by this method, and hence a study was made of changes in body composition in relation to age, since large changes are known to occur in early life in Clethrionomys ( $\mathrm{S}$ a w i c k a -Kapusta, 1974; Fedyk, 1974). Bailey, Kitts \& Wood (1960) proposed that the ratio of protein content to water content could act as an index of physiological age. Although major changes in body composition have been demonstrated in C. gapperi ( $\mathrm{P}$ e r r in, in prep. b), at ages prior to molar root development, variability in protein content and hydration may be sufficient to invalidate the use of Bailey's index in C. gapperi. In fact, until it has been demonstrated that Bailey's index is more reliable than increases in body weight (or body length) in field populations of Clethrionomys, the latter will be used in ageing young voles as they are simpler to measure.

The interpretation of population age structure (Fig. 4) is based on three assumptions that have been derived from the results of this study, i.e., (1) molar roots develop at approximately 84 days of age, (2) the rate of growth of molar roots in the wild is given by $158 x$, where $x=$ increase in molar root length ( $\mathrm{mm}$ ), and that (3) voles without molar roots can be aged by body weight. The method assumes that molar roots develop at the same age in both laboratory and field situations, and that increase in body weight from birth to 84 days is similar in the laboratory and field. These relationships could be tested in a field enclosure, to further substantiate the proposed ageing technique.

Acknowledgements: I wish to express my gratitude, thanks and appreciation for the help that I have received from the members of staff of the Environmental Research Branch, Whiteshell Nuclear Research Establishment, Pinawa, Manitoba, and in particular to Dr. S. L. Ivers on for making the study possible. The project was conducted whilst I was in receipt of a National Research Council of Canada Postdoctoral Research Fellowship, and was financed by Atomic Energy of Canada Limited. 


\section{REFERENCES}

1. Askaner T. \& Hansson L., 1967: The eye lens as an age indicator in small rodents. Oikos, 18: 151-153.

2. B a il e y C. B., Kitts W.D. \& Wood A. J., 1960: Changes in the gross chemical composition of the mouse during growth in relation to the assessment of physiological age. Can. J. Anim. Sci., 40: 143-155.

3. Fedyk A., 1974: Gross body composition in the postnatal development of the bank vole. I. Growth under laboratory conditions. Acta theriol., 19: 381-401.

4. $\mathrm{H}$ a g e n B., 1955: Eine neue Methode der Altersbestimmung von Kleinsäugern. Bonn. Zool. Beitr., 6: 1-7.

5. Ha itlinger R., 1965: Morphological analysis of the Wroclaw population of Clethrionomys glareolus (S chre be r, 1780). Acta theriol., 10: 243-27?.

6. Iverson S. L. \& Turner B. N., 1973: Habitats of small mammals at Whiteshell Nuclear Research Establishment. Atomic Energy of Canada Limited Report AECL 3956.

7. K a c z marski F., 1966: Bioenergetics of pregnancy and lactation in the bank vole. Acta theriol., 11: 409-417.

8. Koshkina T. V., 1955: A method for determination of the age of common red-backed voles and experience of its application. Zool. Zhurn., 34: 621-639 [In Russian].

9. Low e V. P. W., 1971: Root development of molar teeth in the bank vole (Clethrionomys glareolus). J. Anim. Ecol., 40: 49-61.

10. Mazak V., 1963: Notes on the dentition in Clethrionomys glareolus ( $\mathrm{S} \mathrm{chre-}$ ber 1780) in the course of postnatal life. Säugetierk. Mitt., 11: 1-11.

11. Perrin M. R., (in prep. a): The role of reproduction, survival and territoriality in the seasonal dynamics of Clethrionomys gapperi populations.

12. Perrin M. R., (in prep. b): Seasonal variation in the weight, body composition and diet of Clethrionomys gapperi in spruce forest.

13. Pucek Z. \& Zejda J., 1968: Technique for determining age in the redbacked vole Clethrionomys glareolus (Schreber, 1780). Small Mammal Newsletter, 2: $51-60$.

14. Prychodko W., 1951: Zur Variabilität der Rötelmaus (Clethrionomys glareolus) in Bayern. Zool. Jb. (Syst.), 80: 482-506.

15. Röhring G. \& B orner C., 1905: Studien über das Gebiss mitteleuropäischer rezenter Mäuse. Arbeit. Kaisarl. Biol. Anst. Land-Forstwirtsch. Berlin., 5: 36$-89$.

16. S a w icka-Kapusta K., 1974: Changes in the gross body composition and energy value of the bank vole during their postnatal development. Acta theriol., 19: $27-54$.

17. Tupikova N. V., Sidorova G. A. \& Konovalova E. A., 1968: A method of age determination in Clethrionomys. Acta theriol., 13: 99-115.

18. Viitala J., 1971: Age determination in Clethrionomys rufocanus (S u ndev a 11). Ann. Zool. Fenn., 8: 63-67.

19. W a silewski W., 1952: Morphologische Untersuchungen über Clethrionomys glareolus glareolus S chreb. Annls Univ. M. Curie-Skłodowska, C, 7: 119-211.

20. Wrangel H., 1939: Beiträge zur Biologie, insbesondere der Fortpflanzunsbiologie der Rötelmaus, Clethrionomys glareolus (S chre ber, 1780) Z. Säugetierk., 14: 52-93. 
21. Zejda J., 1960: The influence of age on the formation of the third upper molar in bank vole, Clethrionomys glareolus (S chreber, 1780) (Mamm. Rodentia). Zool. Listy., 9: 159-166.

22. $\mathrm{Zejda}$ J., 1061: Age structure in populations of bank vole, Clethrionomys glareolus S chreber, 1780. Zool. Listy., 10: 249-264.

23. Z i mmerman K., 1937: Die märkische Rötelmaus (Analyse einer Population). Märkische Tierwelt., 3: 24-40.

Accepted, December 5, 1977.

\section{ADDENDUM}

The failure of the released voles to become established may have been due to several causes, e.g., (1) competition with resident voles, (2) dispersal, (3) predation and (4) changes due to the transfer from laboratory to field conditions. The first cause seems unlikely since many resident voles were previously removed. Dispersal and predation may have accounted for some loss but are not thought to have been the sole or major causes since wole density was artificially low and there was no sign of weasel (Mustela erminea and $M$. rixosa) activity on this grid. It appears that laboratory-reared voles high mortality due to changes, e.g., in climatic conditions or food availability, associated with the transfer from laboratory to field conditions. In future studies voles should either be reared in outside enclosures and provided with natural food, or field-caught voles should be treated with the alizarine dye and then released. It is unlikely that the staining technique was a cause of mortality because voles kept in the laboratory survived well for several weeks before release.

\section{R. PERRIN}

\section{DEUGOSC KORZENI ZĘBOW JAKO WSKAŹNIK WIEKU \\ U CLETHRIONOMYS GAPPERI}

\section{Streszczenie}

Zbadano zmiany długości korzeni zębów trzonowych u nornic Clethrionomys gapperi $\mathrm{z}$ populacji zamieszkującej lasy borealne poludniowo-wschodniej Manitoby. Zęby trzonowe nornic wyrzynają się $w$ wieku około trzech miesięcy po czym zachodzi bezpośrednia zależność liniowa między długością pierwszego korzenia pierwszego dolnego zęba trzonowego i wiekiem zwierzęcia. Tempo wzrostu nie zależy od pory roku. Nie zaobserwowano żadnych zasadniczych różnic między płciami pod względem tempa wzrostu korzeni zębów trzonowych, tak u zwierząt hodowanych w laboratorium jak u rosnących dziko. Zaobserwowano jednakże zasadnicze różnice w tempie wzrostu nornic hodowanych w laboratorium i zlapanych dzikich nornic. Wiek młodych nornic nie posiadających zębów trzonowych oceniono na podstawie ciężaru ciała. 